\title{
APPLICATION OF VISUAL COMPUTER SIMULATION IN INDUSTRIAL ERGONOMICS
}

\author{
AHMAD RASDAN ISMAIL * \\ KHAIRUL AZHAR MAT DAUD ** \\ NIK ZULKARNAEN KHIDZIR *** \\ MOHD FIRUZ MOHD ANWAR **** \\ MOHD FIRDAUS MAHAMAD ALI ***** \\ DARLIANA MOHAMAD *****
}

\begin{abstract}
Abstrak
Pekerja industri adalah lebih mudah untuk terdedah kepada ketidakselesaan dan kesakitan semasa kerja. Faktor-faktor risiko pekerjaan merupakan faktor terbesar kepada masalah-masalah kesihatan dan ia boleh didapati di mana-mana sektor. Di negara perindustrian, anggota badan bahagian atas lebih terdedah kepada gangguan musculoskeletal. Work-related musculoskeletel disorders (WMSDs) merupakan gejala di mana pekerja akan mengalami kesakitan dan ketidakselesaan di leher, kawasan bahu, belakang, siku, tangan, badan dan lutut, dan juga pada sendi yang sakit, keletihan dan cedera. Namun terdapat kekurangan kajian dalam bidang ini yang memberi tumpuan dan pendedahan tentang kepentingan implikasi rekabentuk kepada manusia. Tambahan pula, terdapat juga kekurangan penyelidikan dalam bidang ini untuk merangkumi masalah yang berkaitan ergonomik kepada manusia dengan menggunakan simulasi komputer. Kertas kerja ini membentangkan tren terkini mengenai penggunaan simulasi komputer visual dalam mendedahkan ketidakselesaan selain gangguan yang dialami oleh pengguna akibat rekabentuk yang tidak ergonomik di tempat kerja atau penggunaan produk mereka. Tiga kajian kes telah dijalankan ke atas penggunaan jenis perisian yang berbeza dalam bidang ergonomik iaitu CATIA-RULA, OWAS dan Pemetaan Tekanan FSA4.0. Dapatan kajian menunjukkan tren WMSDs di kalangan pengguna adalah membimbangkan dan sangat penting untuk keselesaan pengguna.
\end{abstract}

Kata Kunci: Ergonomik, Simulasi berkomputer, WMSD, Keselesaan

* Prof. Madya dan Ketua Unit Pengurusan Persekitaran, Keselamatan Dan Kesihatan Pekerjaan, Universiti Malaysia Kelantan.

** PhD, Timbalan Dekan di Fakulti Teknologi Kreatif dan Warisan, Universiti Malaysia Kelantan

*** PhD, Timbalan Dekan di Fakulti Teknologi Kreatif dan Warisan, Universiti Malaysia Kelantan

**** Pensyarah di Fakulti Teknologi Kreatif dan Warisan, Universiti Malaysia Kelantan

***** Pensyarah di Fakulti Teknologi Kreatif dan Warisan, Universiti Malaysia Kelantan

***** Pensyarah di Fakulti Teknologi Kreatif dan Warisan, Universiti Malaysia Kelantan 


\begin{abstract}
Industrial workers are easier to expose to discomfort and pain during work. The occupational risk factors are the biggest factors to these health problems and it can be found in any industries. In industrialized countries, upper limb work-related musculoskeletal disorders are the most common form of occupational diseases. WMSDs are symptoms where workers will experience pain and discomfort in the neck, shoulder area, back, elbow, hand, trunk and knee, and also joint that they feel pain, fatigue and hurt. Yet there is a lack of study in this field that focuses and reveals the significance of the design implication towards human beings. Furthermore, there is also a lack of research in this particular area that covers the associated problem of ergonomics to the human by utilizing computer simulation. This paper presents the latest trend on the utilization of visual computer simulation in revealing the discomfort as well as the disorder experienced by the user due to the un-ergonomic design of their workplace or products. Three case studies were carried out the utilization of the different type of software available in the field of ergonomics namely CATIA-RULA, OWAS and Pressure Mapping FSA4.0. The finding indicates that the trend of WMSDs among the user were alarming and dramatically significant to the comfort of the user.
\end{abstract}

Keywords: ergonomics, computer simulation, WMSD, comfort.

\footnotetext{
* Prof. Madya dan Ketua Unit Pengurusan Persekitaran, Keselamatan Dan Kesihatan Pekerjaan, di Universiti Malaysia Kelantan.

** PhD, Timbalan Dekan di Fakulti Teknologi Kreatif dan Warisan, Universiti Malaysia Kelantan

*** PhD, Timbalan Dekan di Fakulti Teknologi Kreatif dan Warisan, Universiti Malaysia Kelantan

**** Pensyarah di Fakulti Teknologi Kreatif dan Warisan, Universiti Malaysia Kelantan

***** Pensyarah di Fakulti Teknologi Kreatif dan Warisan, Universiti Malaysia Kelantan

****** Pensyarah di Fakulti Teknologi Kreatif dan Warisan, Universiti Malaysia Kelantan

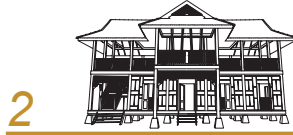




\subsection{Introduction}

Industrial workers are easier to expose to discomfort and pain during work. The occupational risk factors are the biggest factors to these health problems and it can be found in any industries (Halim et al 2005). In industrialized countries, upper limb work-related musculoskeletal disorders (UL-WMSDs) are the most common form of occupational diseases. After receiving rather little attention throughout the first half of the 20th century, work-related musculoskeletal disorders (WMSDs) have become one of the main focus in the area of occupational disease prevention (Colombini \& Occhipinti 2006). WMSDs is a symptom where workers will experience pain and discomfort in the neck, shoulder area, back, elbow, hand, trunk and knee, and also at the joint that they feel pain, fatigue and hurt. (Bernard et al 1994; Lemasters et al 1998).

\subsection{Methodology}

Overall research methodology is indicated in Figure 1. One industrial worker has been chosen as a subject. A complete one cycle of work has been performed by the subject to know whether the worker is experiencing any discomfort during working hours or not. Subsequently, the subject working posture is recorded through video recording. Every posture is measured according by its degree and this information is used as an input in the software computer simulation to model an exact manikin. The postures are viewed from the Mid Sagittal plane. Finally the analysis result is obtained and improvement has been done on the posture problems.

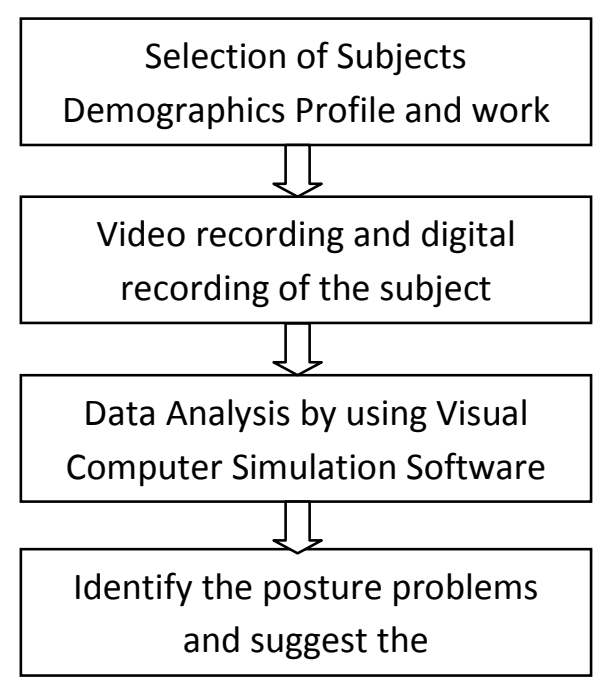

Figure 1: Overall research methodology 


\subsection{Case studies}

3.1 Case study One: Posture Loading CATIA V5 - RULA

RULA (rapid upper limb assessment) is a tool which allows for evaluation of the loads sustained by the musculoskeletal system due to work posture, muscle use and force exerted and calculation on the exposure to risk factors associated with work-related upper limb disorders (McAtamney and Corlett 1993). Massaccesi et al (2003) state that RULA is a method to evaluate and study about the connection between the occupational risk factors and the upper limb disorders. Literally, RULA analysis is used to record information such as the worker posture degree, the load carried by the worker and also whether the postures are static or repeated. The information available is used as an input in the CATIA P3 V5R14 software.

Subject is clearly experiencing posture discomfort during work as indicated in Figures 2 and 3 . The working posture degree is measured and modeled in CATIA V5R14 software. All postures are done using RULA analysis to know the subject level of discomfort. This analysis also shows the body segments that are having problems.

Posture 1 is the first step in the working cycle where the worker needs to lift a $39.4 \mathrm{~kg}$ load from the product original place. The product is lifted by manual handling without robot or machine assistance. Figure 2 shows natural body posture and Figure 3 is simulated body posture.

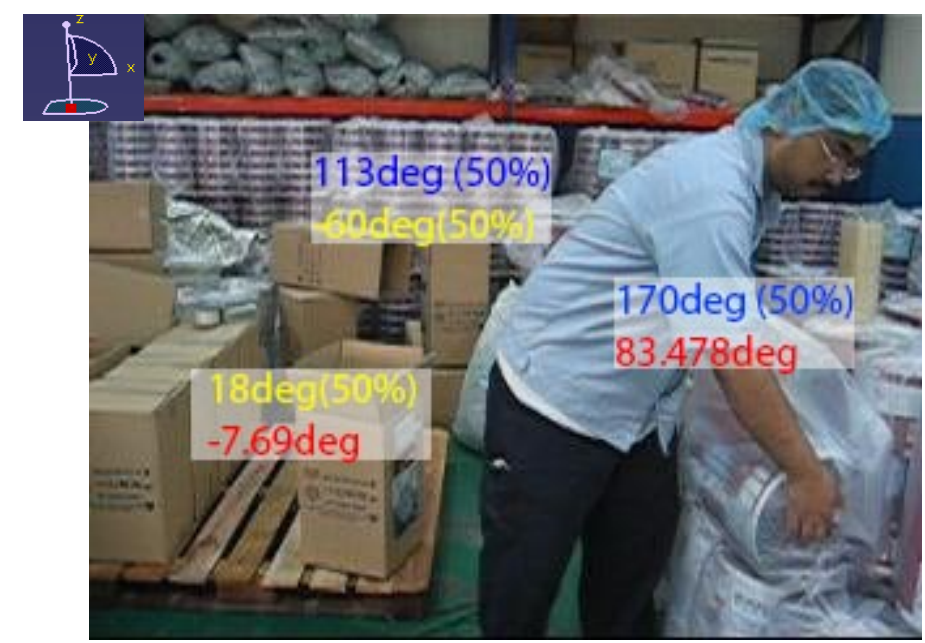

Figure 2: Natural body posture

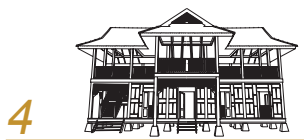




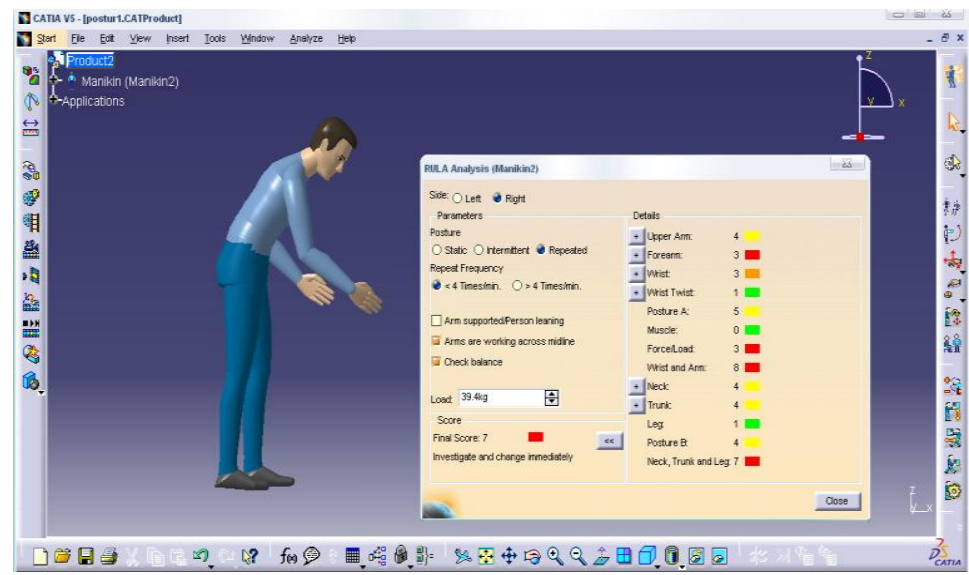

Figure 3: Simulated body posture

From RULA analysis in Figure 3 , it can be seen that the posture level is 4 and red in color. This shows that investigation and changes are required immediately. The problems are detected around the forearm, upper arm, wrist and trunk. The problem is also detected from the load carried by subject. The subject is clearly experiencing posture discomfort during work from the case study form given. The postures are recorded from the working cycle and will be analyzed through the software. Body parts that are having problems will be shown by RULA analysis. Action level with their score and color is shown in Table 1.

New posture improvement has been done immediately to overcome the problem. Figure 4 shows the new improvement of posture 1 and the new RULA analysis result. It shows better results from the previous posture. The changes that have been done on the hand of subject modeling in order to reduce the discomfort is shown in Figure 5. Even though only small changes are involved but it brings a lot of improvement for the posture. Figure 6 also shows the change that has been done on the hand of subject modeling in order to reduce the discomfort but it is for the Flexion/Extension movement. 
Table 1 Action level with their score and colour

\begin{tabular}{|c|c|c|l|}
\hline ACTION LEVEL & COLOR & $\begin{array}{l}\text { RULA } \\
\text { SCORE }\end{array}$ & \multicolumn{1}{|c|}{ STATEMENT } \\
\hline 1 & 1 Or 2 & $\begin{array}{l}\text { Posture is acceptable if it is } \\
\text { not maintained or repeated for } \\
\text { long periods of time. }\end{array}$ \\
\hline 2 & & 3 Or 4 & $\begin{array}{l}\text { Indicates that further } \\
\text { investigation is needed and } \\
\text { changes may be }\end{array}$ \\
\hline 3 & & 5 Or 6 & $\begin{array}{l}\text { Investigation and changes } \\
\text { are required soon. }\end{array}$ \\
\cline { 1 - 1 } & & 7 Or 8 & $\begin{array}{l}\text { Investigation and changes } \\
\text { are required immediately. }\end{array}$ \\
\hline & & & \\
\cline { 1 - 1 } & & &
\end{tabular}

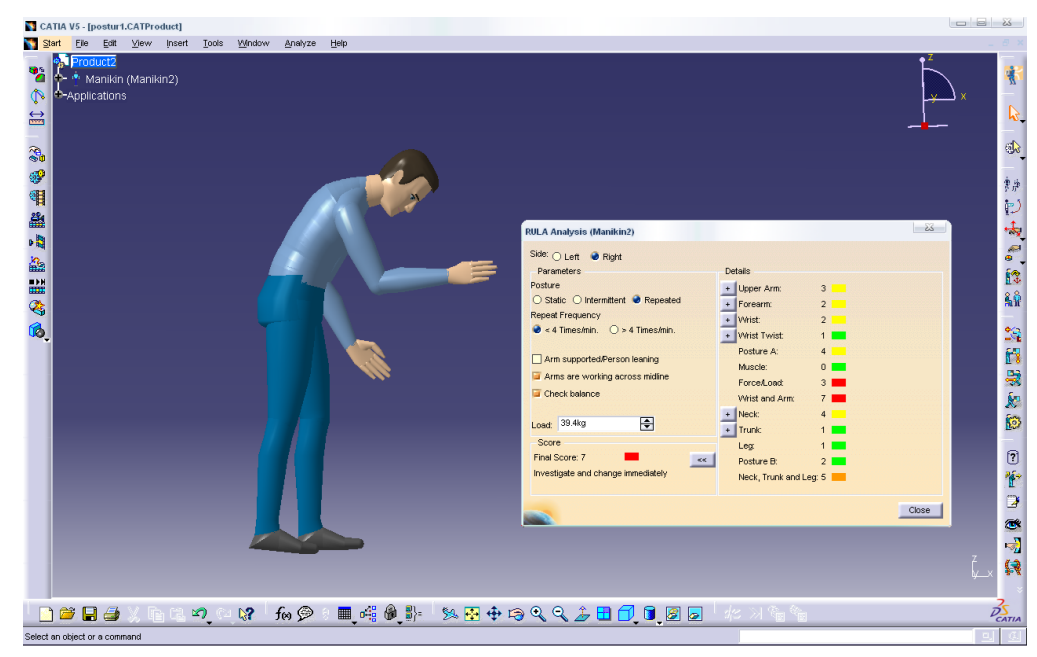

Figure 4: The Changes at Hand for Radial Deviation 


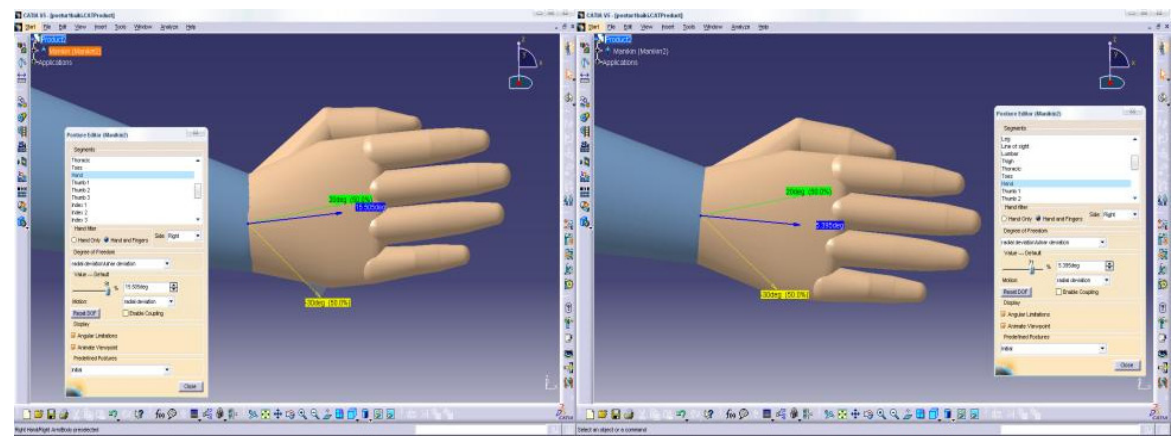

Figure 5: The Changes at Hand for Flexion/Extension

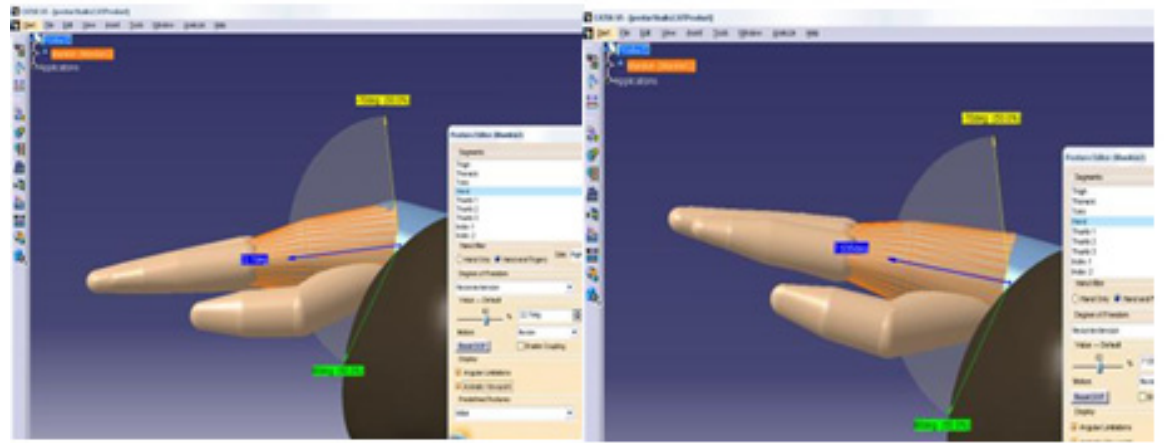

Figure 6: The Changes at the Hand for Flexion/extension Movement

Figure 7 is the changes at the forearm for flexion/extension movement. Subject should lift the load nearer to the body to avoid excessive load and also other discomfort such as back pain.

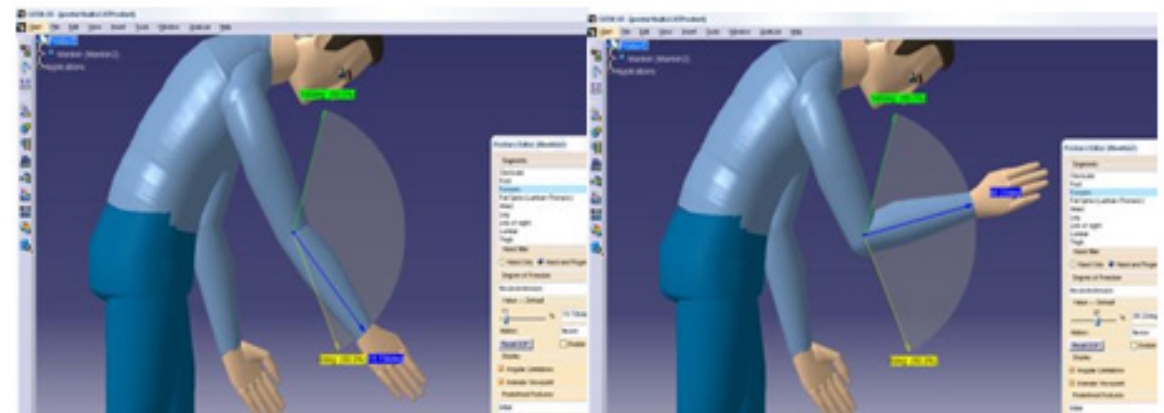

Figure 7: The Changes at the Forearm for Flexion/extension Movement

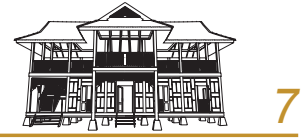


Even though the correction has been done on posture 1 but the final score is still at level 7 . This is attributable to the load the subject carried. The load will bring problem for the subject working posture because of repetitive works. That is why even though subject can handle the load but it will still bring discomfort problem on the muscle and nerves for a long term range. From RULA analysis, if the load is reduced, the working posture will be acceptable.

\subsection{Case Study Two: Posture Loading OWAS}

The OWAS method collects observation information on worker postures on back, arms and legs. It has $252(4 \times 3 \times 7 \times 3)$ posture and load combination, which are combination of four back postures, three arm postures and seven leg postures with three estimate loads. The each OWAS posture code then will be analyzed by using the individual OWAS classified posture combination to get the action category for each work phase. The classification for individual posture combination indicates the level of risk injury for the musculoskeletal system. If the risk for musculoskeletal disorder is high, then the action category indicates the need and urgency for corrective actions. Nine postures will be selected from the original video image to put into the frames. Figure 8 shows the nine postures selection from the original video image and Figure 9 shows the activities of the nine postures.

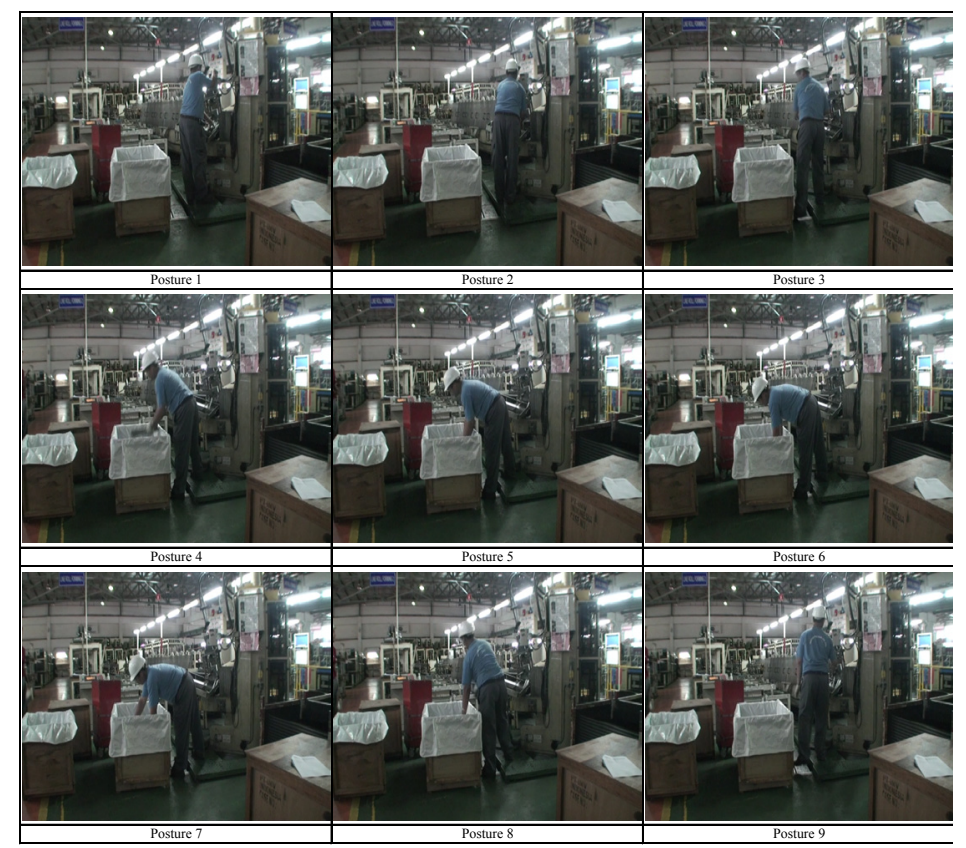

Figure 8: Selected frames from the original video image

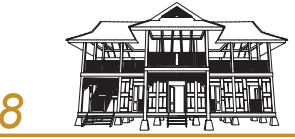




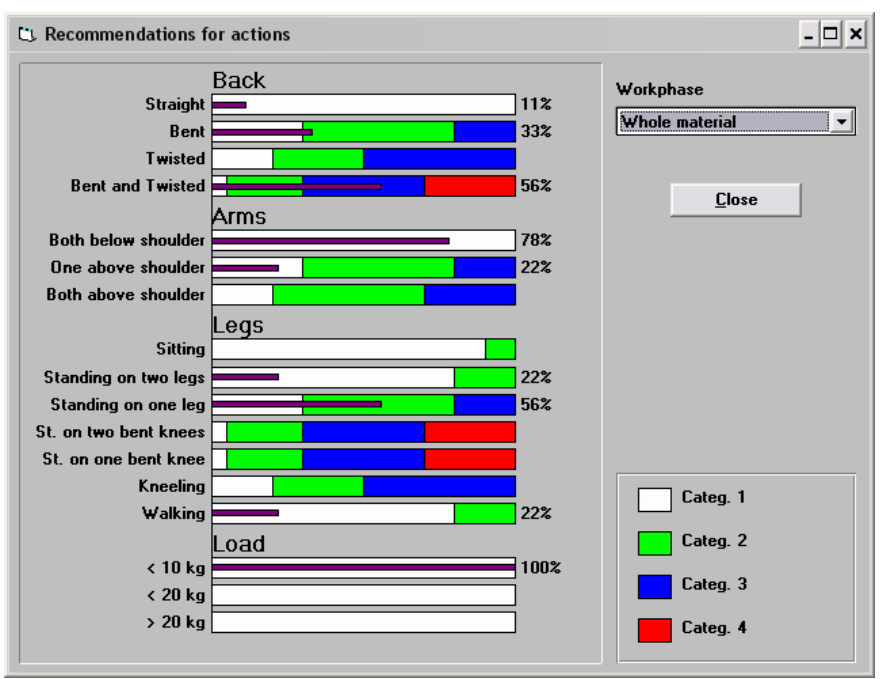

Figure 9: OWAS action category with calculated total time spent in different postures for each body part

\subsection{Case Study Three: Mapping FSA4.0}

The main purpose of this study is to establish the comfort zone for bus drivers in a seated position. In addition, this study is to investigate the seated pressure distribution among Malaysian bus drivers. The study consists of 10 bus drivers randomly selected to be a part of this study. The FSA pressure mat was utilized in order to investigate the force distribution of buttock to the seat pan of the driver's seat. This device is placed on the driver seat and backrest. Later, the subject would sit on for several minutes. The finding reveals that most of the bus drivers feel discomfort by having low back pain and musculoskeletal disorder. The seat pressure distribution of Malaysian bus drivers. The seat is indicated not able to absorb high pressure generated from buttock that later may cause discomfort and restricted the performance of drivers.

Body posture seems to have a complex and non linear effect on acceleration transmissibility; the apparent mass of the seated human body, posture influence is less than the acceleration magnitude effect. Our model aims to analyze in-depth such a relationship. Many professional drivers report that posture (torso positioned almost vertically) would improve ride comfort. Different pressure levels between bilateral lower body parts in a driving posture are expected due to the different task and postural requirements placed on each lower extremity. For example, the right foot, used to control pedals, is required to take more restricted postures with less consistent support, while the left foot,

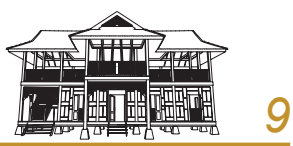


unless a clutch pedal is considered, is relatively free and consistently supported by the car floor or the foot rest. Due to this, the left foot (and the left lower limb) might be involved more dominantly in postural balance, which would result in a bilaterally asymmetric posture and pressure. Indeed, the preferred driving posture has been shown to be asymmetric (Hanson et al, 2006).

Table 2 shows the result of pressure distribution for a seat. The minimum pressure for all seats is (Pmin $=0 \mathrm{mmHg}$ ) because there are some points not involving pressure. The pressure for the seat is actually from thigh to buttock. The results show that seat $\mathrm{G}$ (high- profile sponge with polyester material cover) the best mechanical performance (Pmax $=144.81 \mathrm{mmHg}$; Pmean $=25.6 \mathrm{mmHg}$; Psd $=30.99 \mathrm{mmHg}$ ) with regard to distribution of pressure and contact surface compared to nine other seats. Otherwise, the maximum pressure distribution (by comparing the Pmean values because of Pmax is almost same) recorded is for seat $\mathrm{J}$ with the mechanical performance (Pmax $=200.0 \mathrm{mmHg}$; Pmean $=40.06 \mathrm{mmHg}$; Psd $=51.25 \mathrm{mmHg}$ ) is the highest pressure compared to nine others. Figure 10 shows the distribution for the contact area for the thigh and buttock.

Table 2: Buttock Seats Pressure Distribution

${ }^{*} \mathrm{~N}=10$. Experiment of pressure distribution with same body mass index (BMI)

\begin{tabular}{|c|c|c|c|c|c|c|}
\hline \multirow{2}{*}{$\begin{array}{l}\text { Type of } \\
\text { seat }\end{array}$} & \multicolumn{3}{|c|}{ Pressure $(\mathrm{mmHg})$} & \multirow{2}{*}{$\begin{array}{l}\text { Variance } \\
(\mathrm{mmHg})\end{array}$} & \multirow{2}{*}{$\begin{array}{l}\text { Standard } \\
\text { deviation } \\
(\mathrm{mmHg})\end{array}$} & \multirow{2}{*}{$\begin{array}{l}\text { Coefficient of } \\
\text { variation } \\
(\%)\end{array}$} \\
\hline & minimum & maximum & average & & & \\
\hline A & 0 & 200 & 36.08 & 1887.91 & 43.45 & 120.42 \\
\hline B & 0 & 200 & 26.72 & 1200.04 & 34.64 & 129.63 \\
\hline C & 0 & 200 & 27.59 & 1837.11 & 42.86 & 155.35 \\
\hline D & 0 & 200 & 36.85 & 2665.48 & 51.63 & 140.1 \\
\hline$E$ & 0 & 200 & 33.23 & 2375.59 & 48.74 & 146.67 \\
\hline $\mathrm{F}$ & 0 & 182.57 & 27.54 & 1183.81 & 34.41 & 126.75 \\
\hline G & 0 & 144.81 & 25.6 & 960.31 & 30.99 & 108.34 \\
\hline $\mathrm{H}$ & 0 & 200 & 30.22 & 2012.13 & 44.86 & 148.42 \\
\hline I & 0 & 200 & 34.73 & 2432.45 & 49.32 & 142.02 \\
\hline $\mathrm{J}$ & 0 & 200 & 40.06 & 2626.57 & 51.25 & 127.94 \\
\hline
\end{tabular}




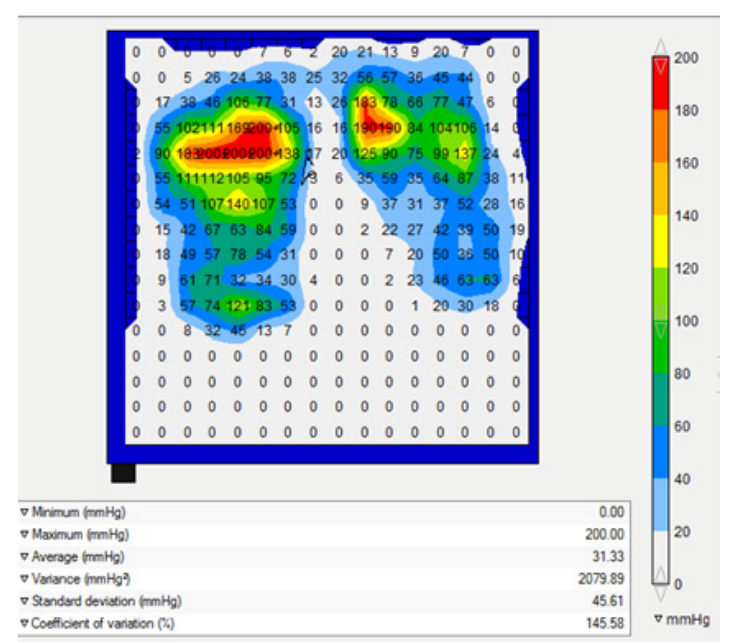

Figure 10: Contact Area for the Tight and Buttock.

There is a significant difference between type of seat materials which are sponge and foam type. The average of mean pressure for a seat with sponge filling material (Pmean $=26.91 \mathrm{mmHg}$ ) and mean pressure for a seat with firm foam filling is (Pmean $=33.98 \mathrm{mmHg}$ ). The correlations between these two types are $r=-0.540$.

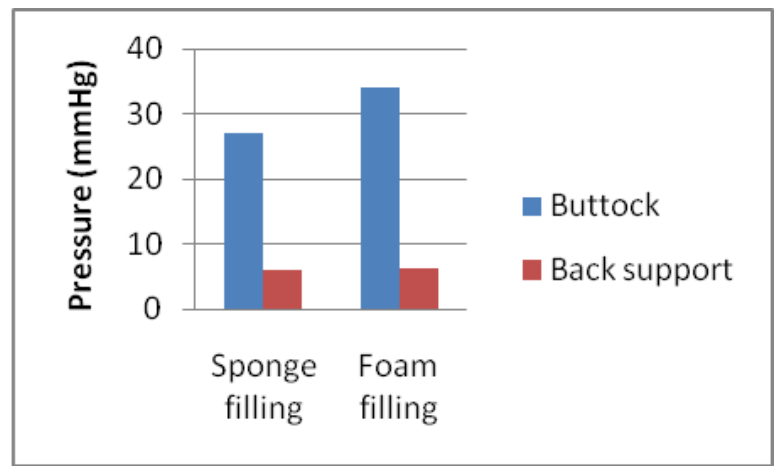

Figure 11: Differences between two type of cushion filling 
However, by referring to Figure 11, there are very small differences of pressure between sponge filling and foam filling. Taking the average of mean pressure, Pmean, for both types, the sponge filling average pressure for back support is (Pavg $=6.07 \mathrm{mmHg}$ ) meanwhile the foam filling is slightly high, which is (Pavg $=6.36 \mathrm{mmHg}$ ). These finding in-line with the Gil et al., (2009) finding whereas they had conducted studies for several types of seat cushion. Their result indicated that the dual-compartment air cushion had the lowest mean pressure, Pmean, which is $34.9 \mathrm{mmHg}$ and the gel and firm foam cushion had the highest Pmean value is $41.9 \mathrm{mmHg}$.

The finding of this particular study also indicates that the lowest mean pressure for high profile sponge is Pmean $=26.91 \mathrm{mmHg}$ then followed by the firm foam cushion which is Pmean $=33.98 \mathrm{mmHg}$ and the highest pressure cushion goes to gel and firm foam cushion at Pmean $=41.9 \mathrm{mmHg}$. According to Lakes et al., (2000), peak pressure is more problematical in a person suffering paralysis, since that pressure may be prolonged, giving rise to pressure sores. Prolonged pressure can inhabit blood flow where the critical pressure for the blood capillary pressure is at $32 \mathrm{mmHg}(4.3 \mathrm{kPa})$.

\subsection{Conclusion}

From this study, three conclusions can be made based on the three case studies:

1) The pressure distribution for seated bus drivers has contributed to the discomfort and may lead to the symptom of back pain and musculoskeletal disorder. The study also reveals that the design of seat for the Malaysian bus drivers should be revaluated for comfort and reduction of back pain symptom.

2) RULA analysis from CATIA P3 V5R14 software is succesful in detecting the problem posture for subject and it can be improved to avoid discomfort.

3) Carry analysis has given the maximum acceptable weight (MAW) subject for every posture. The study done shows that the problem will occur for subject chosen.

The improvement for the working posture can help subject to avoid discomfort. Besides, the production rate where subject is working is expected to increase. This expectation can be proved from the studies done by Vink et al. (2006) which stated that if improvement is done on the workstation for ergonomic reason the production rate will be increased. But, the value of the productivity cannot be known for its exact value because of limited information from company. 


\section{References}

Bernard, B., Sauter, S. and Fine, L. (1994.) Job task and Psychosocial Risk Factors For Work-Related Musculoskeletal Disorders Among Newspaper Employees. Scand. J Work Environ Health 20(6), pg 417-426.

Colombini, D., and Occhipinti, E. (2006.) Preventing Upper Limb Work Related Musculoskeletal Disorders (UL-WMSDS): New Approaches in Job (re)design and Current Trends in Standardization. Applied Ergonomics, Issues 37, pg 441-450.

Halim, I., Omar, A.R. and Saad, N.H. (2005.) Ergonomic Assesment to Identify Occupational Risk Factor in Metal Stamping Industry. NAME 05.

Lemaster, G. K., Atterbury, M. R., Booth-Jones, A.D., Bhattacharya, A., Ollila-Glenn, N., Forrester, C., Forst, L. (1998.) Prevalence of Work Related Musculoskeletal Disorders In Active

Massaccesia, M., Pagnottaa, A., Soccettia, A., Masalib, M., Masieroc, C., Grecoa, F.(2003.) Investigation of work-related disorders in truck drivers using RULA method. Applied Ergonomics, Issues 34, pg 303-307.

Mc Atamney, L.,Corlett, E.N., (1993.)Rula: Innovative Design Of Knock-Down System For Metal Cabinet Appl. Ergon. Issues 24, pg 91-99.

Hanson, L., Sperling, L., Akselsson, R., (2006.) Preferred car driving posture using 3-D information. International Journal of Vehicle Design 42 (1-2), 154-169. 